\title{
Plant Treatments of EAF Slag for its Use as Construction Materials
}

\author{
Qixing Yang ${ }^{1, a}$, Björn Haase ${ }^{2, b}$, Fenglan $\operatorname{Han}^{3, c}$, Anjun $\mathrm{Xu}^{4, d}$, \\ Fredrik Engström ${ }^{1, e}$, Jianli $\mathrm{Li}^{4, f}$ and Bo Björkman ${ }^{1, \mathrm{~g}}$ \\ ${ }^{1}$ Minerals and Metals Research Laboratory, Luleå University of Technology, SE-971 87, Luleå, \\ Sweden \\ ${ }^{2}$ Höganäs Sweden AB, SE-263 83 Höganäs, Sweden \\ ${ }^{3}$ School of Material Science and Engineering, Beifang University of Nationality, Yinchuan, Ningxia \\ 750021, China \\ ${ }^{4}$ Department of Ferrous Metallurgy, School of Metallurgical and Ecological Engineering, University of \\ Science and Technology Beijing, 100083 China \\ a qixing.yang@ltu.se, 'Bjorn.Haase@hoganas.com, '625477897@qq.com, danjunxu@126.com, \\ efredrik.i.engstrom@Itu.se, 'lijianlisteel@163.com, ${ }^{\mathrm{g}} \mathrm{Bo}$.Bjorkman@Itu.se
}

Keywords: EAF, Slag, Steel, Stabilizer, Treatment, Construction

\begin{abstract}
At the steel plant of Höganäs Sweden AB, different steel grades were produced using an Electric Arc Furnaces (EAF). The slag tapped by the EAF often disintegrated during cooling. Slag fines from the disintegration are difficult to handle and to use as materials in construction. The plant tests of EAF slag treatments using stabilizer MCP-F of high $\mathrm{P}_{2} \mathrm{O}_{5}$ content were thus conducted, with $1^{\text {st }}$ and $2^{\text {nd }}$ campaign adding 10 and $20 \mathrm{~kg} \mathrm{MCP-F/ton} \mathrm{slag,} \mathrm{respectively.} \mathrm{The} \mathrm{MCP-F} \mathrm{addition} \mathrm{in} \mathrm{slag}$ pots and other test operations were carried out smoothly, without impacting the EAF steel production. Rates $\mathrm{P}_{2} \mathrm{O}_{5}$ recovery in the EAF slag were lower in some test heats. Studies may thus be carried out in future to increase the $\mathrm{P}_{2} \mathrm{O}_{5}$ recovery from MCP-F, hence, achieving a higher efficiency of stabilization treatments for the slag from the EAF plant.
\end{abstract}

\section{Introduction}

Höganäs Sweden AB has several plants in Sweden. Steel grades of low carbon contents are produced in one of the plants by an Electric Arc Furnace (EAF) for metal powder production. Near the end of steelmaking process, liquid slag was tapped from the EAF in slag pots to transport to slag yards of the plant for pouring on the ground. The EAF slag often disintegrated during the ground cooling, generating slag powder [1-2].

The EAF slag powder can induce air pollution. The slag powder is also difficult to handle and to use as construction materials [1-3]. Results from early studies related the slag disintegration to the transformation of $\beta-\gamma$ phase for dicalcium silicate, $\mathrm{C}_{2} \mathrm{~S}$, which is a major mineral phase in some EAF and AOD slags [1-3]. It is thus necessary to stabilize the $\beta-\mathrm{C}_{2} \mathrm{~S}$ phase by treating the EAF slag, thus, to prevent the $\gamma-\mathrm{C}_{2} \mathrm{~S}$ formation and slag disintegration.

The Minerals and Metals Recycling Research Centre, MiMeR, at Luleå University of Technology, LTU, and Höganäs Sweden AB started joint research work to treat the disintegrated EAF slag. The research work was performed as a part of the work for project 88033 in the research program "Towards a Closed Steel Ecocycle" [4]. The program was administrated by Jernkontoret, with financial support provided by the Foundation for Environment Strategic Research, MISTRA, together with some industry partners in Sweden. The project 88033 was aimed to enhance utilizations of slags from steelmaking processes as construction materials.

In the first stage of the research work, laboratory treatments were carried out to stabilize $\beta-\mathrm{C}_{2} \mathrm{~S}$ in the EAF slag samples from Höganäs Sweden $\mathrm{AB}$ by using stabilizers containing $\mathrm{P}_{2} \mathrm{O}_{5}$ and by fast cooling via air granulation. Samples from the laboratory slag treatments were characterized. Researchers from some Chinese universities also joined some parts of the treatment tests and characterization, financially supported by Chinese foundations and the CAMM, Center for Advanced Mining and Metallurgy, at LTU. 
Based on results from the laboratory treatment tests, treatment tests for the EAF slag in plant scale were carried out at the steel plant in the second stage of the research work. Two test campaigns were carried out to stabilize EAF slag using a stabilizer of high $\mathrm{P}_{2} \mathrm{O}_{5}$. The slag after the stabilization was cooled in air and by water, furnishing samples of large amounts for later long-term aging and stability tests. In this paper, some details of test operations and results are described, which may be helpful for steel plants in both Sweden and China to treat steel slags with low volume stability, hence, enhancing future utilizations of the slags as materials in construction.

\section{Steelmaking Operations of the EAF at the Plant}

EAF steelmaking at the plant proceeded generally by first charging and melting scrap, coke breeze, calcined dolomite $(\mathrm{CaO} 62 \%, \mathrm{MgO} 36 \%)$ and sand, Fig. 1. Near the time of complete material melting, an oxygen injection started for steel refining. The steel, after the refining and sampling, was tapped with a weight of 48.5 ton. The time of tap to tap and the electric power-on for an EAF heat was 82 and 51 minutes, respectively.

After starting the oxygen injection, the slag began to foam and to flow out of the slag door down into the slag pot under the EAF, as seen in Fig. 2A. The flowing-out of foamed slag, the slag tapping, lasted for 15-20 minutes. The tapped slag continued to foam inside the pot until C-O reactions in the slag have finished. Sometimes the foaming was intensive, increasing slag volume and surface level that caused a slag over-flow out of the pot. Water spray on slag surface was practiced to control the intensity for the slag foaming in the pot. The slag over-flowed and solidified outside the pot, while being accumulated to a big amount in a period of around 24 hours, was removed by a digging machine.

Each EAF heat tapped around 2 tons of slag. The pot was with a capacity of four tons or slag tapped from two EAF heats. After slag tapping from the $2^{\text {nd }}$ EAF heat, the pot nearly full up with slag was transported by a slag car to slag yard for pouring, Fig. 2B. Very soon after the pouring, the slag was cooled by water spray and then removed from tipping base to other storage places.

\begin{tabular}{|c|c|c|c|c|c|}
\hline \multicolumn{6}{|c|}{ Steelmaking operations of EAF at the steel plant } \\
\hline \multirow{2}{*}{$\begin{array}{c}\text { Charging 1st } \\
\text { bucket: } \\
\text { Scrap, Coke } \\
\text { breeze, Calcined } \\
\text { dolomite, Sand } \\
\text { Melting }\end{array}$} & \multirow{3}{*}{$\begin{array}{c}\text { Charging } \\
2^{\text {nd }} \text { bucket: } \\
\text { Scrap } \\
\text { Melting }\end{array}$} & \multicolumn{4}{|c|}{$\begin{array}{l}\text { Out: } \text { Steel }\left(1632^{\circ} \mathrm{C}\right) 48.5 \text { ton, } \\
\text { Slag around } 2 \text { ton }\end{array}$} \\
\hline & & \multirow{2}{*}{$\begin{array}{l}\mathrm{O}_{2} \text { gas } \\
\text { injection } \\
\text { Refining }\end{array}$} & \multirow{2}{*}{$\begin{array}{l}\text { Slag flow } \\
\text { out of slag } \\
\text { door down } \\
\text { in slag pot }\end{array}$} & \multicolumn{2}{|c|}{$\begin{array}{l}\text { Time (minute) } \\
\text { Tap-Tap: } 82 \\
\text { Power-on: } 51 \\
\end{array}$} \\
\hline & & & & \multirow{2}{*}{$\begin{array}{l}\text { Sampling of } \\
\text { steel: } \\
\text { Temperature } \\
\text { Analysis }\end{array}$} & \multirow[b]{2}{*}{$\begin{array}{c}\text { Steel } \\
\text { tapping }\end{array}$} \\
\hline \multirow{2}{*}{\multicolumn{3}{|c|}{$\begin{array}{c}\text { In (ton): Scrap 51.4, Coke breeze 1.17, } \\
\text { Calcined dolomite } 0.65 \text {, Sand } 0.38 \\
\mathrm{O}_{2} \text { gas } 286 \mathrm{NM}^{3} \\
\text { Electric energy } 540 \mathrm{Kwh} / \text { ton }\end{array}$}} & & & \\
\hline & & & & \multicolumn{2}{|c|}{$\begin{array}{l}\text { Slag in pot poured } \\
\text { after } 2 \text { heats }\end{array}$} \\
\hline
\end{tabular}

Fig. 1 Chart of EAF steelmaking operations at the plant of Höganäs Sweden AB 


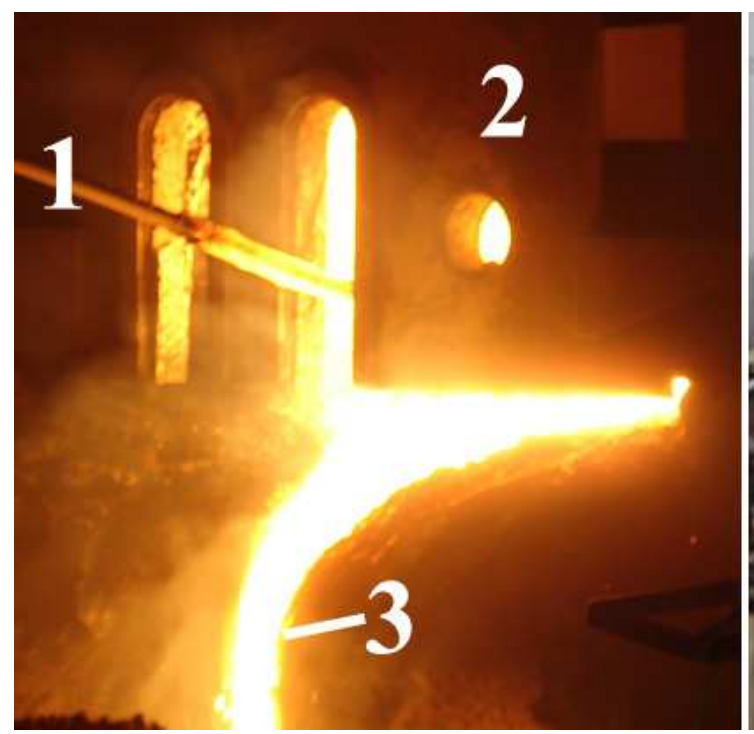

A

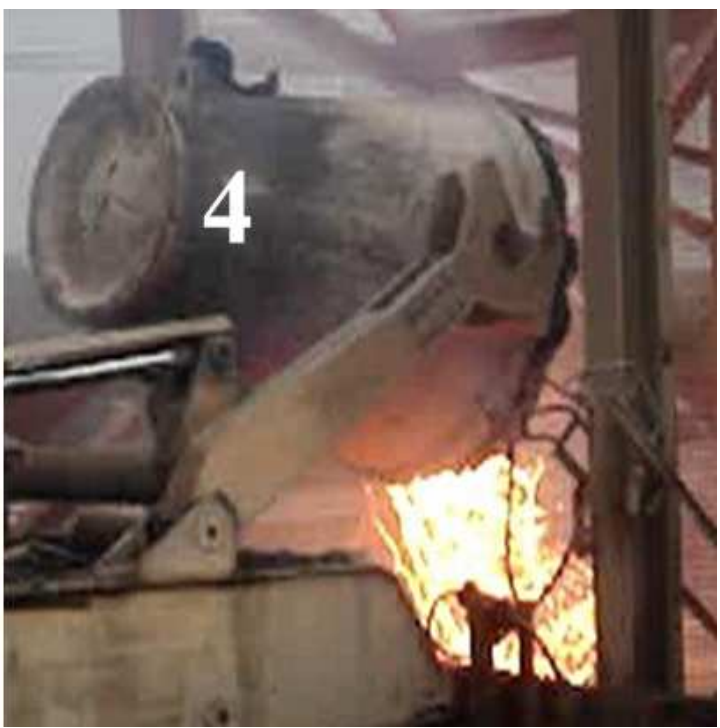

$\mathrm{B}$

Fig. 2 A- Oxygen injection in the EAF for steel refining and slag foaming: 1. Oxygen lance, 2. Slag door, 3. Liquid EAF slag flowing out the door and down in slag pot under furnace, B- Pot tilted for slag pouring: 4. Slag Pot

\section{Operations of EAF Slag Treatments of Plant Scale}

The Stabilizer. MCP-F has been chosen as the stabilizer to treat the EAF slag. Contents of some oxides are listed in Table 1 for the stabilizer MCP-F, which is a feed grade mono-calcium phosphate with $\mathrm{P}_{2} \mathrm{O}_{5}$ of $47.2 \%$, a bulk density of around $1.0 \mathrm{~kg} / \mathrm{m}^{3}$ and sizes of $0.2-1.5 \mathrm{~mm}$, Fig. 3A. A Netzsch STA instrument for thermo-gravimetric analyses, TG, equipped with a supplemental quadropole mass spectrometer was used to heat the MCP-F in Ar gas. The TG results indicated a weight loss of $22.7 \%$ at $1400^{\circ} \mathrm{C}$, due to $\mathrm{H}_{2} \mathrm{O}$ and $\mathrm{CO}_{2}$ evolving from MCP-F at the temperature near $200^{\circ} \mathrm{C}$ and about $900^{\circ} \mathrm{C}$, respectively.

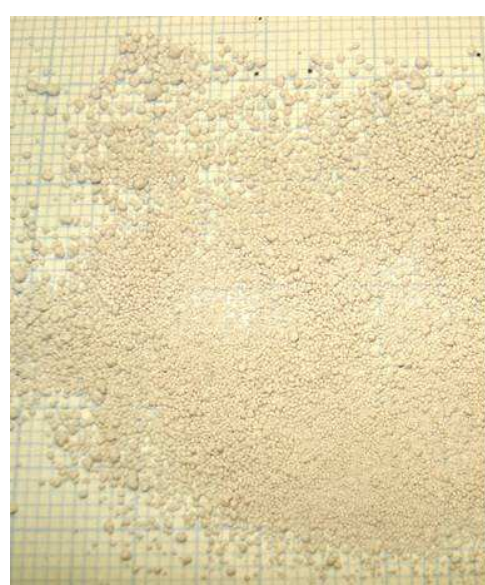

A

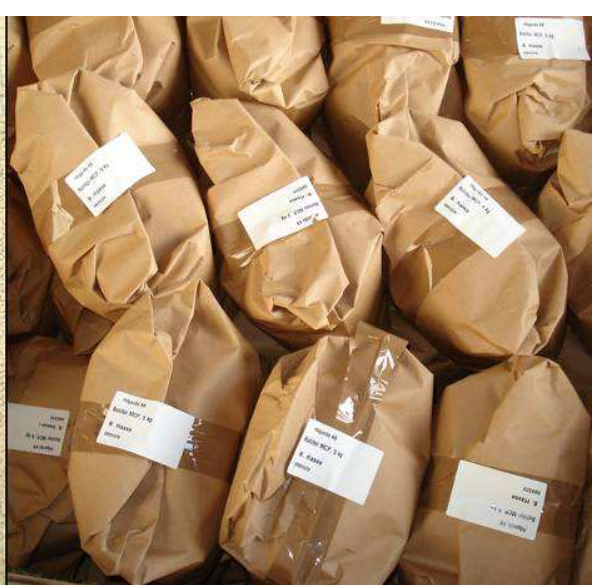

B

Fig. 3 A- Appearance of MCP-F granules, B- Paper bags each containing $5 \mathrm{~kg}$ of MCP-F

Results of the early laboratory treatments for the EAF slag demonstrated that $\mathrm{P}_{2} \mathrm{O}_{5}$ content may be increased to about $0.7 \%$ by adding MCP-F for the slag stabilization [2]. The calculations of MCP-F additions in the EAF slag were performed to aid test planning with results shown in Table 2. Paper bags, each bag containing $5 \mathrm{~kg}$ of MCP-F, Fig. 3B, were used to facilitate the MCP-F additions in EAF slag in the plant treatment tests. 
Table 1 Oxide contents in stabilizer MCP-F, [mass\%]

\begin{tabular}{|c|c|c|c|c|c|c|}
\hline & $\mathrm{CaO}$ & $\mathrm{SiO}_{2}$ & $\mathrm{MgO}$ & $\mathrm{P}_{2} \mathrm{O}_{5}$ & $\mathrm{Al}_{2} \mathrm{O}_{3}$ & $\mathrm{MnO}$ \\
\hline Stabilizer MCP-F & 44.8 & 0.9 & 3.6 & 47.2 & 0.4 & 0.2 \\
\hline
\end{tabular}

Table 2 Results from calculations of MCP-F additions in the EAF slag

\begin{tabular}{|c|c|c|}
\hline \multicolumn{2}{|c|}{ MCP-F added in EAF slag } & $\begin{array}{c}\text { P } \mathrm{P}_{2} \mathrm{O}_{5} \text { increase, [mass\%], in } \\
\text { EAF slag by MCP-F addition* }\end{array}$ \\
\hline$[$ mass\%] & {$[\mathrm{kg}$ MCP-F/ton slag] } & 0.472 \\
\hline 1.0 & 10 & 0.944 \\
\hline 2.0 & 20 & En \\
\hline
\end{tabular}

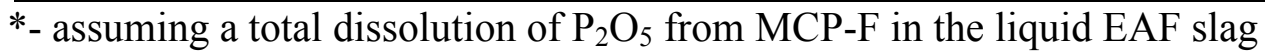

Procedures and Operations for Treatments of the EAF Slag at the Plant. The slag treatments at the plant were designed with purposes to develop optimum procedures for stabilizer additions in liquid EAF slag without disturbing the normal steelmaking operations and to acquire slag samples of larger amounts for later investigations and tests on slag properties.

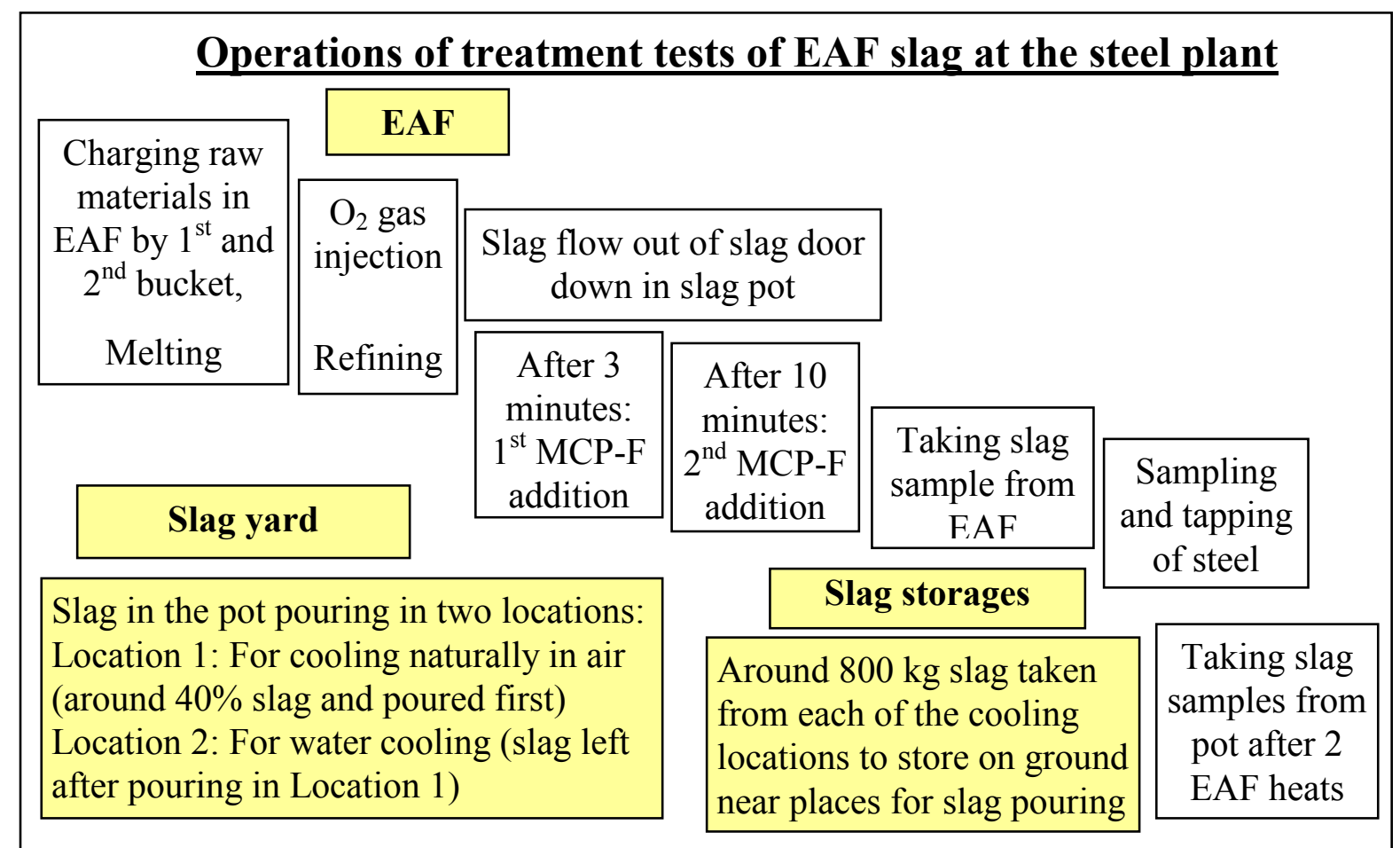

Fig. 4 Chart of operations for EAF slag treatment tests at the plant of Höganäs Sweden AB

Following points were included in the test design and operations (also refer to Fig. 4):

1. EAF heats producing steel quality of A100SH were chosen for the slag treatment tests. The tests consisted of two campaigns, with EAF heats in $1^{\text {st }}$ campaign and in $2^{\text {nd }}$ campaign adding 10 and $20 \mathrm{~kg} \mathrm{MCP-F/ton} \mathrm{slag} \mathrm{or} 4$ and $8 \mathrm{MCP}-\mathrm{F}$ bags/EAF heat, respectively, assuming each of the EAF heats tapping out slag of 2 tons. In each of the campaigns there were also several reference heats without any MCP-F addition.

2. MCP-F was added by manually throwing MCP-F bags $(5 \mathrm{~kg} / \mathrm{bag})$ in the slag pot, Fig. 5 , after starting of $\mathrm{O}_{2}$ injection/slag tapping by two additions. The $1^{\text {st }}$ addition started 3 minutes after the tapping, throwing $50 \%$ of the bags in the pot and $2^{\text {nd }}$ addition started 10 minutes after the tapping, throwing rest of the bags. The $2^{\text {nd }}$ addition was performed about 5 minutes before finishing the slag tapping.

3. Near the end of slag tapping, samples were taken from both slag and steel inside the EAF. 
4. A sample was taken from slag pot while the slag pot containing slag tapped from two EAF test heats was lift for transporting to slag yard for pouring.

5. There were two locations at the slag yard to pour the slag tapped from the test heats, location 1 to which about $40 \%$ of slag poured first for cooling naturally in air and location 2 to which the rest of slag poured for water cooling.

6. Samples, each weighing around $800 \mathrm{~kg}$, were taken from the slag poured in different locations and then stored separately on ground near places for the slag pouring.

The slag tests were performed smoothly according to the above design and the chart in Fig. 4. Fig. 5 shows a picture of MCP-F addition in one of the test heats with number 81363. A slag splashing was observed occurring just after a MCP-F bag being added in the slag pot, 4 in Fig. 5.

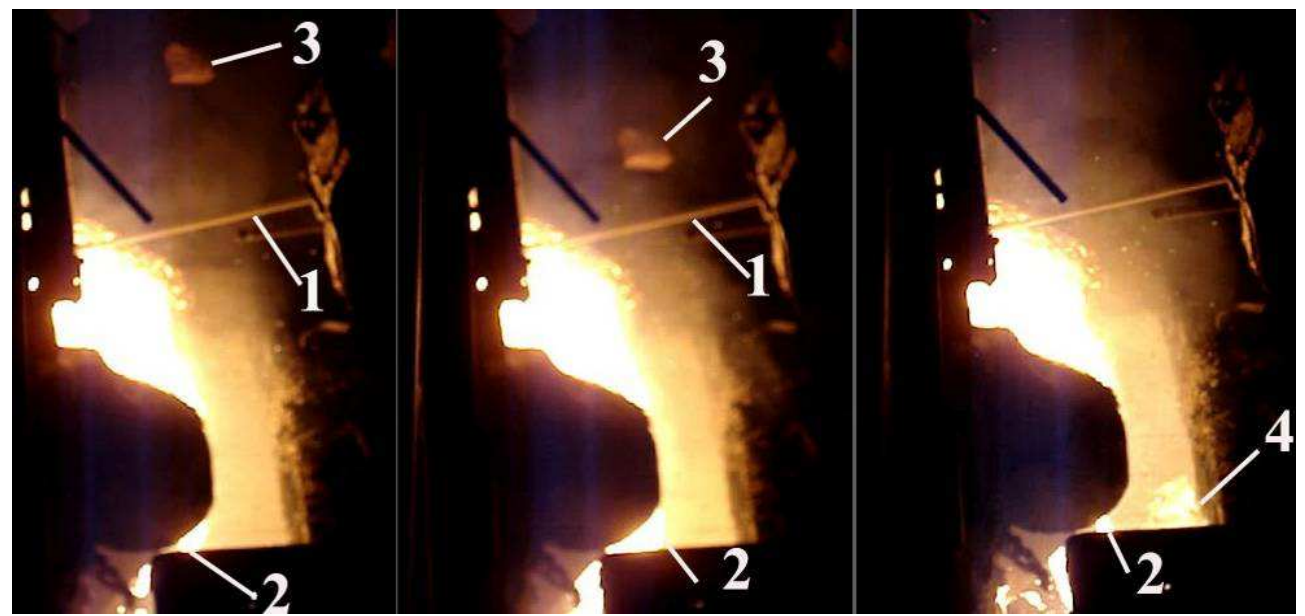

Fig. 5 Pictures of MCP-F addition in test heat 81363: 1. Lance for $\mathrm{O}_{2}$ injection, 2. Liquid slag flowing out the EAF slag door and down into slag pot, 3. A MCP-F bag cast down manually into the slag pot, 4. Liquid slag splashed just after the addition of the MCP-F bag

\section{Results from the EAF Slag Treatments at the Steel Plant}

Contents of Some Elements in Steel Samples from the Test Heats. Values of [P], i.e. mass\% of $P$ in steel, for samples taking inside furnace near the time of slag tapping are rather low for the test EAF heats and similar to the reference heats, Table 3. Values of [S] and [P] were rather similar, showing that there was no negative impact of the slag tests on refining of $\mathrm{S}$ and $\mathrm{P}$ and the quality of steel tapped from the EAF.

Table 3 Element contents in steel samples taken from EAF during the slag treatment tests of $1^{\text {st }}$ and $2^{\text {nd }}$ campaign adding 20 and $40 \mathrm{~kg} \mathrm{MCP-F/heat,} \mathrm{respectively}$

\begin{tabular}{|c|c|c|c|c|c|c|c|}
\hline $1^{\text {st }}$ campaign & \multicolumn{3}{|c|}{$[\mathrm{mass} \%]$} & $2^{\text {nd }}$ campaign & \multicolumn{3}{c|}{$[\mathrm{mass} \%]$} \\
\hline Heat number & $\mathrm{C}$ & $\mathrm{Mn}$ & $\mathrm{P}$ & Heat number & $\mathrm{C}$ & $\mathrm{Mn}$ & $\mathrm{P}$ \\
\hline 81329 & 0.566 & 0.139 & 0.005 & 81345 (Reference) & 1.734 & 0.270 & 0.022 \\
\hline 81330 & 0.687 & 0.195 & 0.008 & 81346 (Reference) & 0.374 & 0.178 & 0.008 \\
\hline 81331 & 1.962 & 0.406 & 0.024 & 81358 & 0.256 & 0.113 & 0.005 \\
\hline 81332 & 0.354 & 0.209 & 0.007 & 81359 & 0.782 & 0.117 & 0.004 \\
\hline 81333 & 0.402 & 0.167 & 0.003 & 81360 & 0.817 & 0.099 & 0.004 \\
\hline 81334 & 0.288 & 0.171 & 0.004 & 81361 & 0.527 & 0.107 & 0.004 \\
\hline 81335 (Reference) & 0.535 & 0.154 & 0.004 & 81362 & 0.711 & 0.130 & 0.005 \\
\hline 81336 (Reference) & 0.616 & 0.200 & 0.008 & 81363 & 0.584 & 0.130 & 0.006 \\
\hline
\end{tabular}

Analyzing, Re-melting and Metal Separation for Slag Samples from the Plant Tests. Slag samples taken inside the EAF and slag pot during the plant slag treatment tests of $1^{\text {st }}$ and $2^{\text {nd }}$ campaign were analyzed, with results listed in Table 4. A part of the slag samples taken inside the EAF, each 
weighing about $0.4 \mathrm{~kg}$, were also re-melted in $\mathrm{MgO}$ crucibles by MiMeR. The sample re-melting was performed in a similar way as for the laboratory slag treatment tests at LTU, heating to $1620^{\circ} \mathrm{C}$ at a rate of $4.2^{\circ} \mathrm{C} /$ minute, holding $1620^{\circ} \mathrm{C}$ for some 20 minutes and then in-furnace cooled to room temperature in about 5 hours [2].

Table 4 Oxides, [mass\%], in slag samples taken inside the EAF and slag pot during the EAF slag treatment tests of $1^{\text {st }}$ and $2^{\text {nd }}$ campaign, "**" denoting samples from reference EAF heat

\begin{tabular}{|r|c|c|c|c|c|c|c|r|}
\hline $1^{\text {st }}$ campaign & $\mathrm{CaO}$ & $\mathrm{SiO}_{2}$ & $\mathrm{Al}_{2} \mathrm{O}_{3}$ & $\mathrm{MgO}$ & $\mathrm{FeO}$ & $\mathrm{MnO}$ & $\mathrm{P}_{2} \mathrm{O}_{5}$ & $\mathrm{CaO} / \mathrm{SiO}_{2}$ \\
\hline 81329 & 39.0 & 13.4 & 5.4 & 7.2 & 25.4 & 3.6 & 0.29 & 2.91 \\
\hline 81330 & 47.1 & 13.3 & 6.1 & 10.9 & 12.4 & 3.0 & 0.32 & 3.54 \\
\hline Pot 81329-81330 & 42.8 & 10.5 & 5.7 & 6.2 & 24.7 & 3.6 & 0.39 & 4.08 \\
\hline 81331 & 38.8 & 9.4 & 4.5 & 8.5 & 27.0 & 5.7 & 0.49 & 4.13 \\
\hline 81332 & 48.8 & 12.8 & 6.0 & 7.6 & 13.3 & 4.2 & 0.45 & 3.81 \\
\hline Pot 81331-81332 & 38.1 & 10.0 & 6.9 & 4.7 & 32.5 & 4.3 & 0.34 & 3.81 \\
\hline 81333 & 44.8 & 11.8 & 8.3 & 5.6 & 16.5 & 4.4 & 0.31 & 3.80 \\
\hline 81334 & 43.5 & 13.2 & 6.5 & 6.2 & 17.4 & 4.5 & 0.35 & 3.30 \\
\hline Pot 81333-81334 & 42.7 & 8.9 & 6.1 & 4.9 & 23.3 & 4.4 & 0.39 & 4.80 \\
\hline$* 81335$ & 44.0 & 11.2 & 5.1 & 8.4 & 19.7 & 3.9 & 0.40 & 3.93 \\
\hline$* 81336$ & 46.7 & 12.4 & 5.6 & 10.0 & 13.1 & 3.8 & 0.41 & 3.77 \\
\hline$*$ Pot 81335-81336 & 41.8 & 8.5 & 4.7 & 11.8 & 27.0 & 3.6 & 0.32 & 4.92 \\
\hline $2^{\text {nd }}$ campaign & & & & & & & & \\
\hline 81358 & 43.6 & 10.4 & 4.4 & 9.8 & 22.0 & 4.3 & 0.47 & 4.19 \\
\hline 81359 & 41.5 & 4.2 & 4.4 & 6.6 & 34.2 & 3.5 & 0.47 & 9.88 \\
\hline 81360 & 31.5 & 5.6 & 3.8 & 5.6 & 46.4 & 4.5 & 0.59 & 5.63 \\
\hline 81361 & 37.0 & 6.7 & 4.7 & 6.2 & 35.7 & 4.8 & 0.49 & 5.52 \\
\hline 81361 & 39.5 & 6.2 & 5.0 & 6.2 & 32.2 & 4.3 & 1.18 & 6.37 \\
\hline 81363 & 31.2 & 7.9 & 5.2 & 5.6 & 41.0 & 6.4 & 0.53 & 3.95 \\
\hline Pot 81358-81359 & 37.6 & 4.9 & 7.6 & 4.0 & 36.0 & 4.0 & 0.75 & 3.94 \\
\hline Pot 81360-81361 & 38.4 & 8.4 & 4.5 & 6.4 & 32.0 & 3.9 & 0.52 & 4.57 \\
\hline Pot 81362-81363 & 32.3 & 8.2 & 6.3 & 4.1 & 35.8 & 5.4 & 0.63 & 3.55 \\
\hline $81345-81346$ & 36.4 & 10.0 & 6.0 & 6.7 & 31.8 & 5.5 & 0.48 & 3.64 \\
\hline
\end{tabular}

Table 5 Element contents in steel samples obtained after slag-metal separation from slag samples taken from the heaps of slag stored on ground after cooling by air (a) or water (w), "*" denoting samples from reference EAF heat

\begin{tabular}{|r|c|c|c|r|c|c|c|}
\hline $1^{\text {st }}$ campaign & \multicolumn{3}{|c|}{$[\mathrm{mass} \%]$} & $2^{\text {nd }}$ campaign & \multicolumn{3}{c|}{$[\mathrm{mass} \%]$} \\
\hline & $\mathrm{C}$ & $\mathrm{Mn}$ & $\mathrm{P}$ & & $\mathrm{C}$ & $\mathrm{Mn}$ & $\mathrm{P}$ \\
\hline $81329-81330-\mathrm{a}$ & 0.069 & 0.12 & 0.016 & $* 81345-81346-\mathrm{w}$ & 0.035 & 0.09 & 0.008 \\
\hline $81331-81332-\mathrm{a}$ & 0.30 & 0.12 & 0.016 & $81358-81359-\mathrm{a}$ & 0.054 & 0.09 & 0.008 \\
\hline $81333-81334-\mathrm{a}$ & 0.020 & 0.11 & 0.008 & $81358-81359-\mathrm{w}$ & 0.034 & 0.11 & 0.012 \\
\hline$* 81335-81336-\mathrm{a}$ & 0.016 & 0.07 & 0.009 & $81360-81361-\mathrm{a}$ & 0.021 & 0.07 & 0.012 \\
\hline$* 81335-81336-\mathrm{w}$ & 0.042 & 0.13 & 0.012 & $81360-81361-\mathrm{w}$ & 0.024 & 0.10 & 0.028 \\
\hline & & & & $81362-81363-\mathrm{w}$ & 0.16 & 0.05 & 0.008 \\
\hline
\end{tabular}

It is seen in the top part of the picture in Fig. 6 that the $\mathrm{MgO}$ crucibles holding some of the slag samples for re-melting were not damaged. The small amounts of slag samples (30-40 g) and sizes of the $\mathrm{MgO}$ crucibles, a height of $72 \mathrm{~mm}$ and a small inner diameter of $20 \mathrm{~mm}$, may become limiting 
factors for slag volume expansion. A later work to determine the stability for the EAF slag from the campaigns may re-melt slag samples with amounts larger than $100 \mathrm{~g}$ in crucibles with larger diameters.

However, cracks, $\mathrm{C}$ in Fig. 6, were found appearing on wall for 2 of the $\mathrm{MgO}$ crucibles one month after the re-melting. The crucibles contained re-melted slag samples taken from the EAF heat 81358 and 81360 in the $2^{\text {nd }}$ campaign. The slag volume expansion may lead to the observed crack formation. The samples of small amounts taking in the EAF may be cooled quickly. The fast cooling may postpone the volume expansion for the re-melted slag. It is thus necessary to obtain samples of large amounts for a long-term aging and storage tests to determine volume stability for a safe utilization of the EAF slag from the plant.

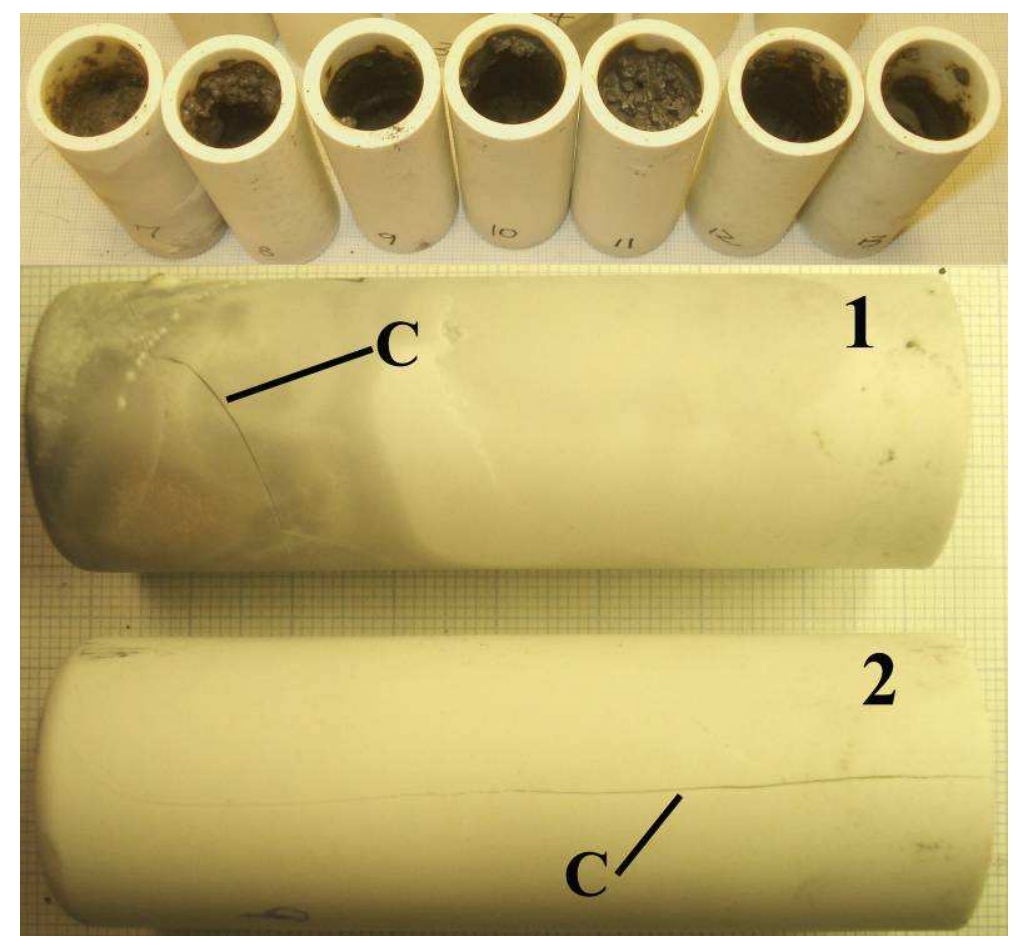

Fig. $6 \mathrm{MgO}$ crucibles containing the re-melted slag samples on top of the picture and cracks on wall of crucible found one month after slag re-melting: 1 and $2 . \mathrm{MgO}$ crucibles containing slag sample taken inside the EAF heat with number 81358 and 81360 , respectively, C. Cracks

Table 6 Oxides, in [mass\%], in slag samples taken from the heaps of slag stored on ground after poured from slag pot and cooled by air (a) or water (w) in $2^{\text {nd }}$ EAF campaign, “*” denoting samples tapped from reference EAF heat

\begin{tabular}{|r|c|c|c|c|c|c|c|}
\hline In 2 ${ }^{\text {nd }}$ campaign & $\mathrm{CaO}$ & $\mathrm{Al}_{2} \mathrm{O}_{3}$ & $\mathrm{MgO}$ & $\mathrm{FeO}$ & $\mathrm{MnO}$ & $\mathrm{P}_{2} \mathrm{O}_{5}$ & $\mathrm{CaO} / \mathrm{SiO}_{2}$ \\
\hline$* 81345-81346-\mathrm{a}$ & 38.4 & 7.8 & 5.2 & 28.4 & 4.9 & 0.57 & 3.05 \\
\hline$* 81345-81346-\mathrm{w}$ & 40.9 & 10.1 & 5.3 & 27.0 & 4.0 & 0.53 & 4.26 \\
\hline $81358-81359-\mathrm{a}$ & 37.9 & 7.4 & 6.1 & 35.1 & 4.1 & 0.87 & 6.77 \\
\hline $81358-81359-\mathrm{w}$ & 34.9 & 9.6 & 4.1 & 32.4 & 4.6 & 2.18 & 2.88 \\
\hline $81360-81361-\mathrm{a}$ & 37.9 & 5.3 & 7.4 & 34.8 & 4.3 & 0.98 & 6.42 \\
\hline $81360-81361-\mathrm{w}$ & 38.3 & 4.8 & 5.4 & 34.9 & 3.4 & 1.16 & 4.51 \\
\hline $81362-81363-\mathrm{a}$ & 34.7 & 6.7 & 5.9 & 35.9 & 5.3 & 0.88 & 3.77 \\
\hline $81362-81363-\mathrm{w}$ & 40.0 & 6.1 & 6.7 & 30.6 & 4.3 & 0.99 & 4.88 \\
\hline
\end{tabular}

Slag samples were taken from the heaps of slag stored on ground after pouring from slag pots to cool by air or water. Steel droplets were separated from the slag samples by MiMeR to obtain steel samples for analyzing. The steel sample $81329-81330$-a contained [C] of $0.069 \%$, Table 5 , which is 
much lower than the $0.626 \%$, the $[\mathrm{C}]$ value obtained by averaging [C] values for steel samples from EAF heat 81329 and 81330, Table 3. There are also large differences in [C] and [Mn] contents for other heat groups as shown in Tables 3 and 5.

Samples taken from slag poured from pots to cool by air or water in $2^{\text {nd }}$ campaign were also obtained for analyzing with results shown in Table 6 . The samples from slag pots contained $\mathrm{FeO}$ of around $30 \%$, Table 4 and 6 , indicating high amounts of Fe oxides in the slag. In a slag pot, the quantity of liquid steel would be much smaller than the quantity of liquid slag. Oxygen in some of the Fe oxides may then easily contact the droplets to oxidize most of $\mathrm{C}$ and $\mathrm{Mn}$ elements, which largely decreased $[\mathrm{C}]$ and $[\mathrm{Mn}]$ in the steel samples retrieved from the slag.

There is one steel sample from slag, 81360-81361-w, containing [P] of $0.028 \%$. Values of $[\mathrm{P}]$ in other samples range $0.008-0.016 \%$, Table 5, with tiny differences between the test and reference heats. A comparison of [P] values shown in Tables 3 and 5 indicates a very little or no dissolution of $\mathrm{P}$ from the added MCP-F in steel droplets. On the other hand, for dissolution of $\mathrm{P}$ in steel, $\mathrm{P}_{2} \mathrm{O}_{5}$ must be reduced first to $\mathrm{P}$ element, which may be impossible in a liquid, oxidizing slag or in the EAF slag with high contents of Fe oxides, Table 4 and 6.

Thus, the steel tapped in the pots with the low [P] values can be recovered from the slag and safely used as scrap for the EAF steelmaking, without impacting on $\mathrm{P}$ content of steel products.

Recovery of $\mathrm{P}_{2} \mathrm{O}_{5}$ from the added MCP-F in the Treated EAF Slag. A complete $\mathrm{P}_{2} \mathrm{O}_{5}$ dissolution or recovery in slag from the added MCP-F increases $\mathrm{P}_{2} \mathrm{O}_{5}$ contents of slag in the pots by 0.472 and $0.944 \%$ in $1^{\text {st }}$ and $2^{\text {nd }}$ campaign, respectively, if each test heat tapping 2 tons of EAF slag, Table 2. $\mathrm{P}_{2} \mathrm{O}_{5}$ contents in slag samples taken before the EAF tapping $\left(\mathrm{P}_{\mathrm{EAF}}\right)$, from slag pot $\left(\mathrm{P}_{\mathrm{Pot}}\right)$ and from the heaps of slag poured to cool by air $(\mathrm{Pa})$ and water $(\mathrm{Pw})$ presented in Table 7 are used in Eq. 1 and 2 to calculate, respectively, theoretical $\mathrm{P}_{2} \mathrm{O}_{5}$ contents of the slag in pot, Pcal, and the recovery of $\mathrm{P}_{2} \mathrm{O}_{5}$ in the slag from MCP-F added, Pre.

Table $7 \mathrm{P}_{2} \mathrm{O}_{5}$ content, [mass\%], in slag samples taken from the EAF (average of two heats), $\mathrm{P}_{\mathrm{EAF}}$, and slag pot, $\mathrm{P}_{\mathrm{Pot}}$, as well as slag samples from the heaps of slag poured from pots and cooled by air (Pa) and water $(\mathrm{Pw})$; Pcal, theoretical $\mathrm{P}_{2} \mathrm{O}_{5}$ content, [mass\%], and Pre, recovery of $\mathrm{P}_{2} \mathrm{O}_{5}$ in slag from added MCP-F, [\%], the Pcal and Pre is calculated by Eq. 1 and 2, respectively

\begin{tabular}{|c|c|c|c|c|c|c|}
\hline In 1 & $\begin{array}{c}\mathrm{P}_{\text {EAF }} \text { campaign } \\
{[\mathrm{mass} \%]}\end{array}$ & $\begin{array}{c}\mathrm{P}_{\text {Pot }} \\
{[\mathrm{mass} \%]}\end{array}$ & $\begin{array}{c}\text { Pa } \\
{[\mathrm{mass} \%]}\end{array}$ & $\begin{array}{c}\text { Pw } \\
{[\mathrm{mass} \%]}\end{array}$ & $\begin{array}{c}\text { Pcal } \\
{[\mathrm{mass} \%]}\end{array}$ & $\begin{array}{c}\text { Pre } \\
{[\%]}\end{array}$ \\
\hline $81329-81330$ & 0.31 & 0.39 & 0.42 & 0.40 & 0.777 & 20 \\
\hline $81331-81332$ & 0.47 & 0.34 & 0.5 & 0.48 & 0.942 & 0 \\
\hline $81333-81334$ & 0.33 & 0.39 & 0.4 & 0.6 & 0.802 & 28 \\
\hline In 2 ${ }^{\text {nd }}$ campaign & & & & & & \\
\hline $81358-81359$ & 0.47 & 0.75 & 0.87 & 2.18 & 1.414 & 84 \\
\hline $81360-81361$ & 0.54 & 1.18 & 0.98 & 1.16 & 1.484 & 60 \\
\hline $81362-81363$ & 0.535 & 0.63 & 0.88 & 0.99 & 1.479 & 32 \\
\hline
\end{tabular}

Pcal $[\mathrm{mass} \%]=\mathrm{P}_{\mathrm{EAF}}+\left(\mathrm{P}_{2} \mathrm{O}_{5}\right.$ increase $)$

$$
\operatorname{Pr} e=\frac{(\mathrm{P} \mathrm{Pot}+\mathrm{Pa}+\mathrm{Pw}) / 3-\mathrm{P}_{\mathrm{EAF}}}{\left(\mathrm{P}_{2} \mathrm{O}_{5} \text { increase }\right)} \times 100
$$

Where in Eq. 1 and 2: $\left(\mathrm{P}_{2} \mathrm{O}_{5}\right.$ increase), [mass\%], - $\mathrm{P}_{2} \mathrm{O}_{5}$ increase in slag by total dissolution of $\mathrm{P}_{2} \mathrm{O}_{5}$ from the added MCP-F, equal to 0.472 and $0.944 \%$ for the EAF slag treated in the $1^{\text {st }}$ and $2^{\text {nd }}$ plant campaign, respectively, Table 2

For first heat group in $1^{\text {st }}$ campaign, $81329-81330, \mathrm{P}_{\mathrm{EAF}}$ is $0.31 \%$, Table 7 , and $\mathrm{Pa}$ and $\mathrm{Pw}$ are near $0.4 \%$, increasing by around $0.1 \%$ but lower by $0.377 \%$ than Pcal of $0.777 \%$, the calculated theoretical $\mathrm{P}_{2} \mathrm{O}_{5}$ content. The $\mathrm{P}_{2} \mathrm{O}_{5}$ recovery in the slag may then be $20 \%$ for the first heat group. Values of Pre may be 0 and $28 \%$ for the two other heat groups in $1^{\text {st }}$ campaign, Table 7 . 
Values of $[\mathrm{Mn}]$ are in a higher range, $0.139-0.406 \%$, in steel samples from EAF heats in $1^{\text {st }}$ campaign, Table 3. Extra lime of 300-600 kg was added through slag door to adjust the steel $\mathrm{Mn}$ contents, which may increase slag weights by more than $300-600 \mathrm{~kg}$. The amount of MCP-F added in slag pot in $1^{\text {st }}$ campaign, $20 \mathrm{~kg} /$ heat, was designed to increase $\mathrm{P}_{2} \mathrm{O}_{5}$ content by $0.472 \%$ in the slag with weigh of two tons. Due to the addition of extra lime to increase slag weights to some 2.6 tons, the $\mathrm{P}_{2} \mathrm{O}_{5}$ content in the slag pots increased slightly for the group of heat 813331-81332 and increased only by $0.1-0.17 \%$ in other two heat groups.

Values of [Mn] ranged 0.099-0.13, Table 3, and there was thus no extra lime needed for the Mn refining in heats of $2^{\text {nd }}$ campaign. Slag weights from the heats may thus be near two tons. Contents of $\mathrm{P}_{2} \mathrm{O}_{5}$ in most of the $\mathrm{Pa}$ and $\mathrm{Pw}$ samples are around $0.9-1.1 \%$, increasing by $0.4-0.5 \%$. The added MCP-F, $40 \mathrm{~kg} /$ heat, may then be recovered in the slag up to $32-84 \%$, Table 7 .

Slag was observed foaming out of the pot caused by $\mathrm{CO}$ gas from $\mathrm{C}-\mathrm{O}_{2}$ reaction. A TG test, heating the MCP-F to $1400^{\circ} \mathrm{C}$ in Ar gas, showed its weight loss of $22.7 \%$, due to $\mathrm{H}_{2} \mathrm{O}$ and $\mathrm{CO}_{2}$ gas formation at high temperature. The emission of the two gases from MCP-F may lead to the observed slag splashing after MCP-F addition, 4 in Fig. 5. Some of the MCP-F added may be foamed or splashed out of the pot together with slag. A foaming or splashing loss of MCP-F would result in $\mathrm{P}_{2} \mathrm{O}_{5}$ loss or a low rate of $\mathrm{P}_{2} \mathrm{O}_{5}$ recovery in the EAF slag.

Future studies may be carried out to develop optimum methods for preventing the foaming or splashing loss of MCP-F or other stabilizers. It may also be needed to accurately determine weights for the tapped slag, by which a proper adjustment of the stabilizer can be made according to changes in the slag weight. With these studies and some other future research work, stabilization operations of the EAF slag will be optimized to make the slag high quality materials suitable for construction applications.

\section{Conclusions}

1. The plant tests of EAF slag treatments consisted of $1^{\text {st }}$ and $2^{\text {nd }}$ campaign, adding 10 and $20 \mathrm{~kg}$ MCP-F/ton slag, respectively. The MCP-F addition in slag pots, sampling of steel and slag in EAF and slag pouring to cool by air and water were carried out smoothly, without disturbing the EAF operation and steel production.

2. Cracks, formed due to slag volume expansion, appeared on wall of two $\mathrm{MgO}$ crucibles one month after the re-melting of slag samples taken from EAF heats in the $2^{\text {nd }}$ campaign. The fast cooling may delay the slag volume expansion, making it necessary to conduct long-term aging and storage tests. The tests will determine volume stability for a safe utilization of the plant EAF slag.

3. $\mathrm{P}$ contents in samples of steel tapped in the slag pots ranged $0.008-0.028 \%$. With the low [P] contents, the steel tapped in slag pots can be recovered and used safely as metallic materials for the EAF steelmaking.

4. Extra lime of $300-600 \mathrm{~kg}$ was added to adjust steel Mn contents in $1^{\text {st }}$ EAF test campaign, which largely increased slag weights, decreasing $\mathrm{P}_{2} \mathrm{O}_{5}$ recovery to $0-28 \%$ in the tapped slag from the added MCP-F.

5. No extra lime was added in $2^{\text {nd }}$ campaign and the $\mathrm{P}_{2} \mathrm{O}_{5}$ recovered in the tapped slag from the added MCP-F was thus in a higher range of $32-84 \%$.

6. Emissions of $\mathrm{CO}$ and $\mathrm{H}_{2} \mathrm{O}$ gas caused slag foaming and splashing. Some of the added MCP-F may be splashed out of the slag pot. Studies may be performed in future to enhance $\mathrm{P}_{2} \mathrm{O}_{5}$ recovery from the added MCP-F, obtaining a higher efficiency of stabilization treatments for the EAF slag.

\section{Acknowledgements}

The authors wish to thank Foundation for Strategic Environmental Research, Mistra, (the steel Eco-Cycle), Höganäs Sweden AB and CAMM, Center for Advanced Mining and Metallurgy at Luleå University of Technology, LTU, for financial support. Mr. Jianli Li has received financial support from the Chinese Scholarship Council, University of Science and Technology Beijing in China and 
CAMM for PhD training at LTU. Besides, researches from Beifang University of Nationality and Luleå University of Technology have been supported by CAMM for visiting and for performing joint research work.

\section{References}

[1] Qixing Yang, et al.: In: REWAS 2008: Global Symposium on Recycling, Waste Treatment. Minerals, Metals \& Materials Society, (2008), p. 49

[2] Qixing Yang, et al.: In: Proceedings of Asia Steel 2012, Sept. 23-27, 2012, Beijing, China

[3] Qixing Yang et al., In: Proceedings of The Iron \& Steel Technology Conference, AISTech 2006, May 1-4, Cleveland, Ohio, USA (2006),Volume 1, p. 573

[4] Information on http://www.jernkontoret.se/english/research/the_steel_eco_cycle/index.php 